\title{
Cost-effectiveness analysis of tank and base foundation diagnostics without paintwork removal
}

\author{
Petr Chepur ${ }^{1}$, Aleksandr Tarasenko ${ }^{1}$, Vadim Krivorotov ${ }^{2}$, Evgeniy Tikhanov $^{2}$, and Alesya \\ Gruchenkova, ${ }^{3, *}$ \\ ${ }^{1}$ Industrial University of Tyumen, 625000 Volodarskogo Street 38, Russia \\ ${ }^{2}$ Ural Federal University named after the first President of Russia B. N. Yeltsin, 620002 Mira Street \\ 19, Russia \\ ${ }^{3}$ Surgut Oil and Gas Institute, 628405 Entuziastov Street 38, Russia
}

\begin{abstract}
The article describes the particular qualities of application of a cylindrical steel tanks' and base foundation technical inspection method without removal of a protective covering. The model is formed and the basic parameters of an estimation of economic efficiency of carrying out of diagnostics are determined. The economic efficiency of application of the modern method of vertical steel tank examination is estimated. The high economic efficiency of the new technological method is substantiated in comparison with the traditional method. It is established that the advantage of using the innovative diagnostic method in comparison with the traditional method is fully manifested when it is necessary to maintain a large fleet of tanks. It is calculated that, given the design parameters, the savings in the use of the method proposed by the authors in the long term are 1773.2 million rubles compared with traditional. The use of a new technological method - the technology of diagnosing vertical steel tanks without removing the protective coating, allows to reduce the total cost of conducting diagnostics with a discount of 8.7 times. Dependences were obtained of the discounted volume of expenses on acquisition of the equipment and the subsequent diagnostics of vertical steel tanks on the operation time of the vertical steel tanks.
\end{abstract}

\section{Introduction}

To ensure the conditions of reliable and safe operation of the pipeline oil transportation system, it is necessary to timely conduct and organize work on the technical diagnostics of its main elements [1-4]. Large vertical steel tanks, being an integral link in the technological chain of pipeline oil transportation, should be in a fault-free condition for the entire period of operation [5-13]. For this purpose, the domestic industry regulations define the terms and volumes of a regular diagnostic examination of the vertical steel tanks. Full technical diagnostics of the tank is carried out on average with a frequency of at least once

\footnotetext{
${ }^{*}$ Corresponding author: alesya2010-11@yandex.ru
} 
in ten years, and partial - once in every five years $[14,15]$. Performing the full technical diagnostics includes: visual inspection control (VIC), ultrasonic thickness measurement (UTM), ultrasonic scanning (US), magnetic inspection (MI), radiographic inspection (RI), acoustic and emission examination (AEE). Using the traditional method (Figure 1), up to $80 \%$ of the cost of conducting a full diagnostic examination of the VST is associated with the work on removing and restoring the anticorrosion coating. However, the development of methods for conducting nondestructive testing and modern equipment with the latest software allow the diagnostics of tanks without removing the protective coating with the specified accuracy and quality according to the reference documentation. The description of the sequence of testing by traditional and innovative methods is presented below.

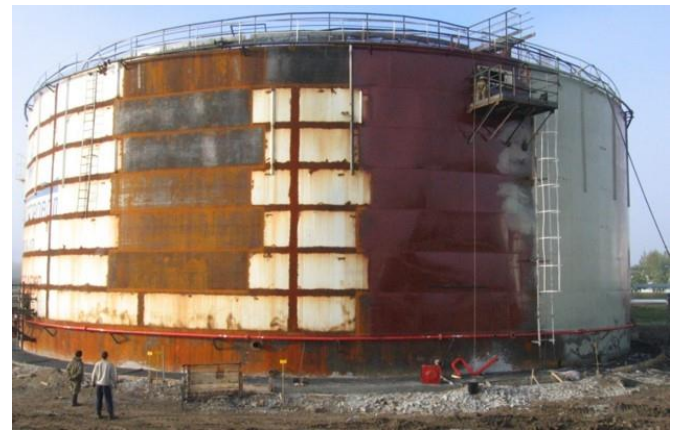

Fig. 1. Operations in the diagnosis of the vertical steel tank by the traditional method.

Stages of carrying out diagnostics using the traditional method:

- cleaning the wall surface of the VST up to the pure metal;

- carrying out all types of non-destructive testing in the volume prescribed by the reference documentation;

- preparation of the tank to the restoration of the protective coating;

- degreasing of the surface to be painted;

- abrasive-jet surface machining;

— surface dedusting;

- coloring the outer surface of the tank in 3 layers;

— tank logo and number drawing;

- paintwork quality control.

Stages of carrying out diagnostics using the innovative method:

- cleaning the surface of dirt, snow, ice, without damaging the protective coating;

- carrying out of the whole complex of diagnostics by methods of nondestructive testing in the volume prescribed by the reference documentation without removing the paintwork. Hence it appears that the application of the first method requires a much larger number of operations, which means a greater amount of labor, the consumption of materials, and as a consequence, the final cost of work will also be much higher.

\section{Methods}

In order to assess the feasibility of acquiring a specialized technical complex consisting of equipment and software that allows full technical diagnostics of vertical steel tanks without compromising the integrity of the protective coating and subsequent application of a modern method of diagnostic inspection of tanks, the authors carried out a comparative analysis of the effectiveness of traditional and innovative (proposed by the authors) methods. The main cost element when using the traditional method is the costs associated 
with the removal and restoration of corrosion protection coatings. Application of the new technology up to 9 times reduces the costs of the operating organization for tank diagnostics, depending on the size of the VST.

When calculating the economic efficiency of the diagnostic inspection of tanks without removing the protective coatings (Table 1), the following parameters are used:

1. The investment phase is considered, consisting of getting the necessary technological equipment and the subsequent eight-year period of diagnostics and operation of the tank battery;

2. Annually, 20 tanks are diagnosed, including five tanks VST-5000, ten VST-10000, and five VST-20000;

3. The cost of works on the complex diagnostics of the VST of the basic sizes is presented in Figure 2.

4. The average annual revenue from the operation of the tank minus current costs is 50 million rubles;

5. Calculation step is 1 year;

6. The discount rate is taken at the level of $14 \%$ with a $100 \%$ share of internal funds.

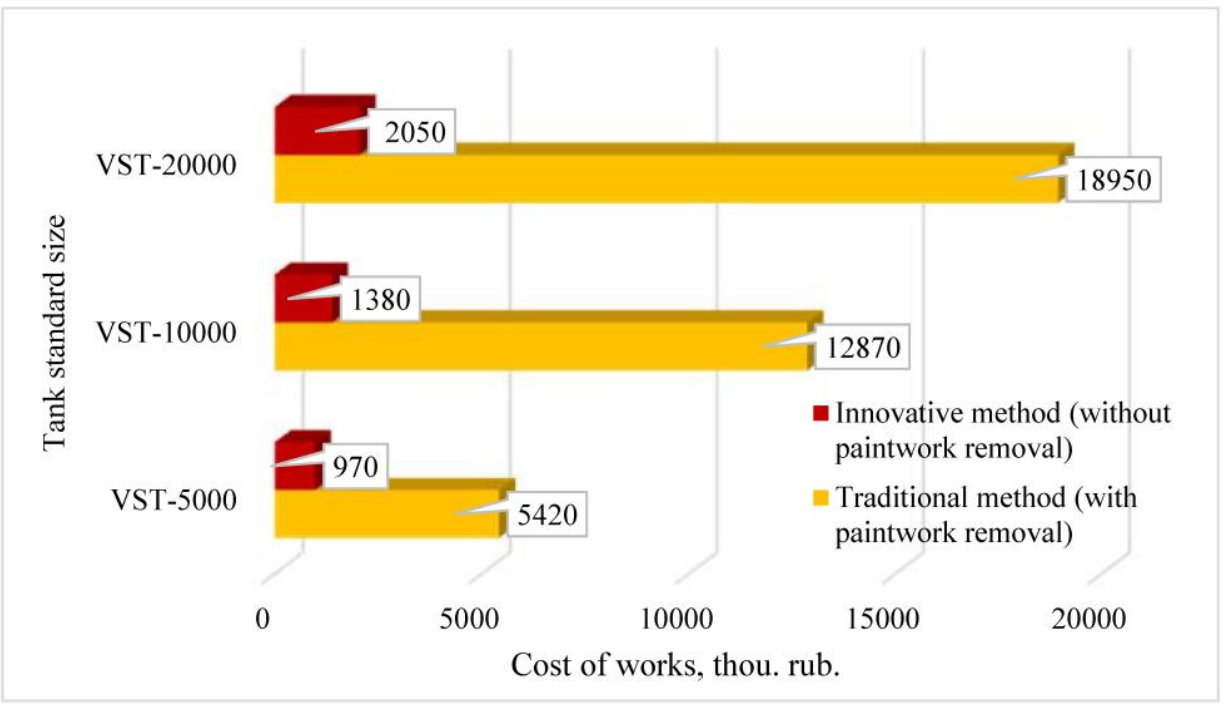

Fig. 2. Cost comparison of carrying out the VST complex diagnostics for the customer by traditional and innovative methods.

\section{Results and discussion}

It should be noted that in order to carry out VST diagnostics without removing the protective coating, equipment is required according to the standard list, as well as additional complexes. The standard equipment includes:

— ultrasonic thickness gauge NDT MG2/D799 «Panametrics»;

— ultrasonic unit «Scanner»;

— magnetic thickness gauge MT2007;

- electrospark holiday detector Krona 2-I;

- X-ray apparatus Arina-5 etc.

The additional equipment required to implement the methodology developed by the authors includes (Figure 3): ultrasonic measuring system with phased array technology 
«OmniScan»; acoustic emission equipment: «Disp», «Samos», preamplifiers and «PAC» converters; magnetic flaw detector Introkor M150.

The analysis shows that the costs associated directly with the diagnostics of vertical steel tanks by the innovative method are 1,773.2 million rubles or 8.7 times less than the similar costs for the diagnostic examination by the traditional method. The effect from the application of the innovative method is fully manifested when it is necessary to maintain a large tank battery. Herewith, the more the number of tanks for which it is necessary to carry out diagnostics is, the more significant the benefits of a more technological method are, as Figure 4 shows.

Table 1. Comparative analysis of the effectiveness of the traditional (with paintwork removal) and innovative (without paintwork removal) methods of diagnostic inspection of vertical steel tanks.

\begin{tabular}{|c|c|c|c|c|c|c|c|c|c|c|}
\hline Index & 2018 & 2019 & 2020 & 2021 & 2022 & 2023 & 2024 & 2025 & 2026 & Total \\
\hline \multicolumn{11}{|c|}{ Cash flows for the tank diagnostics project } \\
\hline \multicolumn{11}{|c|}{ Expenses for additional equipment, mln. rub. } \\
\hline $\begin{array}{l}\text { Innovative } \\
\text { method }\end{array}$ & 7.7 & - & - & - & - & - & - & - & - & 7.650 \\
\hline $\begin{array}{l}\text { Traditional } \\
\text { method }\end{array}$ & 0 & - & - & - & - & - & - & - & - & 0 \\
\hline \multicolumn{11}{|c|}{ Expenses for the diagnosis, mln. rub. } \\
\hline $\begin{array}{l}\text { Innovative } \\
\text { method }\end{array}$ & - & 28.9 & 28.9 & 28.9 & 28.9 & 28.9 & 28.9 & 28.9 & 28.9 & 231.2 \\
\hline $\begin{array}{l}\text { Traditional } \\
\text { method }\end{array}$ & - & 250.6 & 250.6 & 250.6 & 250.6 & 250.6 & 250.6 & 250.6 & 250.6 & 2004.4 \\
\hline $\begin{array}{l}\text { Cash flows } \\
\text { from the } \\
\text { operation of } \\
\text { the tank }\end{array}$ & - & 1000 & 1000 & 1000 & 1000 & 1000 & 1000 & 1000 & 1000 & 8000 \\
\hline \multicolumn{11}{|c|}{ Total net cash flow, mln. rub. } \\
\hline $\begin{array}{l}\text { Innovative } \\
\text { method }\end{array}$ & -7.7 & 971.1 & 971.1 & 971.1 & 971.1 & 971.1 & 971.1 & 971.1 & 971.1 & 7768.8 \\
\hline $\begin{array}{l}\text { Traditional } \\
\text { method }\end{array}$ & 0 & 749.5 & 749.5 & 749.5 & 749.5 & 749.5 & 749.5 & 749.5 & 749.5 & 5995.6 \\
\hline $\begin{array}{l}\text { Discount } \\
\text { rate, } \%\end{array}$ & 14 & & & & & & & & & \\
\hline $\begin{array}{l}\text { Discount } \\
\text { coefficient }\end{array}$ & 1.00 & 0.88 & 0.77 & 0.67 & 0.59 & 0.52 & 0.46 & 0.40 & 0.35 & \\
\hline \multicolumn{11}{|c|}{ Cash flow, taking into account the discount, mln. rub. } \\
\hline $\begin{array}{l}\text { Innovative } \\
\text { method }\end{array}$ & -7.7 & 851.8 & 747.2 & 655.5 & 575.0 & 504.4 & 442.4 & 388.1 & 340.4 & 4504.8 \\
\hline $\begin{array}{l}\text { Traditional } \\
\text { method }\end{array}$ & 0 & 657.4 & 576.7 & 505.9 & 443.7 & 389.2 & 341.4 & 299.5 & 262.7 & 3476.6 \\
\hline
\end{tabular}
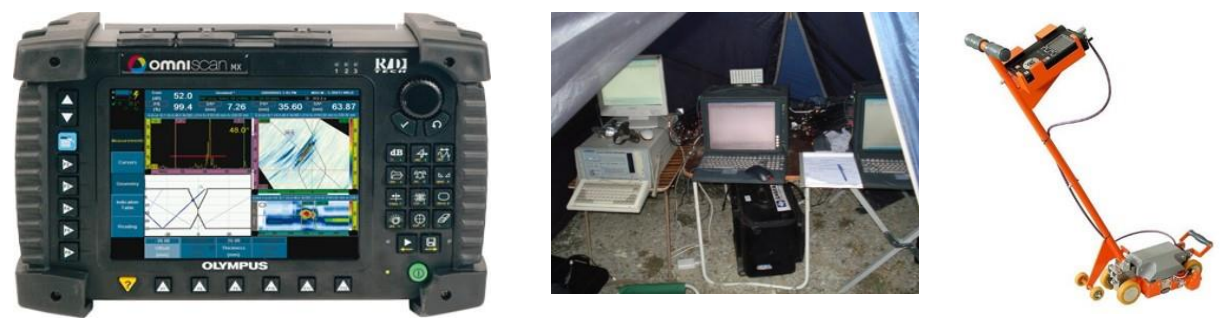

Fig. 3. The additional equipment required to implement the methodology. 


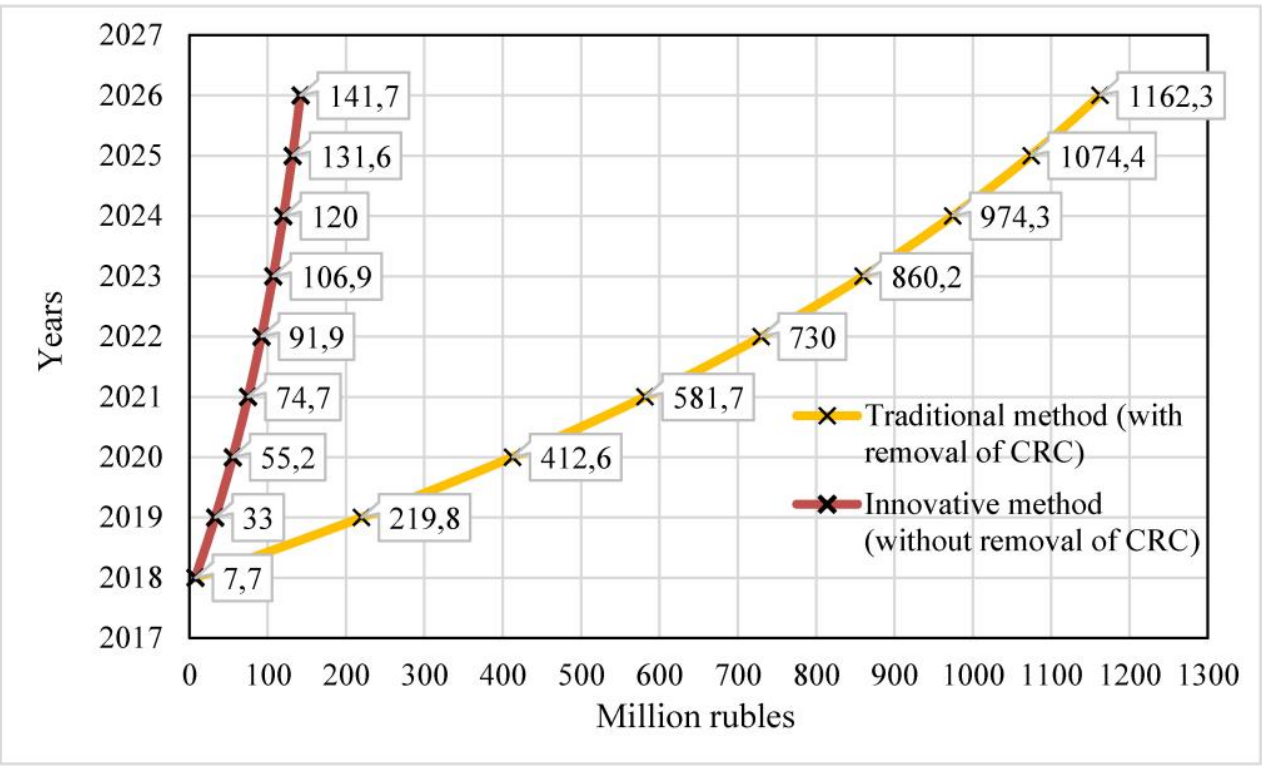

Fig. 4. Discounted amount of costs for equipment purchase and subsequent diagnostics of vertical steel tanks.

The aggregate cash flow of the operating organization, taking into account the discounting for 9 years under consideration, with the initial investment in equipment equal to 7.7 million rubles, in case of applying the innovative method, will be $29.4 \%$ or 1020.6 million rubles higher than the corresponding figure for using the traditional method of tank diagnostics.

Summarizing, we can say that investing a relatively small amount of funds in the purchase of new technological equipment that allows to diagnose vertical steel tanks without removing the anticorrosion coating, operating organizations get the economic effect of saving on costs in tens and even hundreds of times greater than the amount of implemented investments.

\section{Conclusions}

The authors in [1] developed a modern method for diagnosing vertical steel tanks, which makes it possible to carry out a survey of a VST without removing the protective coating with a specified accuracy and quality that is not inferior to the traditional method. Based on this development, an analysis of its economic efficiency and the expedience of its application is carried out. The efficiency of the innovative diagnostic method in comparison with the traditional method is fully apparent when it is necessary to maintain a large tank battery. For the given design parameters (Table 1), the savings in the use of the method proposed by the authors are $1773.2 \mathrm{mln}$. rub. in the long term by contrast to the traditional one. The use of a new technological method - diagnosing VST without removing the protective coating, allows reducing the total cost of conducting diagnostics with a discount of 8.7 times. In addition, the dependences of the discounted amount of costs for purchasing the equipment and subsequent diagnostics of vertical steel tanks from the operation time of the VST are obtained. The aggregate cash flow of the operating organization is calculated using both traditional and innovative methods for the full technical diagnosis of tanks. 


\section{Acknowledgments}

The paper was prepared within the implementation of the basic part of the government task for the project № 7.7858.2017/BP: "Development of the scientific principles of the techniques for determining the stress-strain state of the large-sized storage tanks during the differential settlement of the substructures and foundations".

\section{References}

1. A.A. Tarasenko, P.V. Chepur, A.E. Sharkov, D.A. Gretchenko, Fundam. Res. 9(8), 1703-1708 (2014)

2. RD-23.020.00-KTN-283-09, Pravila remonta i rekonstruktsii rezervuarov dlya khraneniya nefti ob"emom 1000-50000 kub. m. (OAO AK "Transneft", Moscow, 2009)

3. A. Tarasenko, A. Gruchenkova, P. Chepur, Proc. Eng. 165, 1125-1131 (2016)

4. A. Gruchenkova, A. Tarasenko, P. Chepur, D. Tarasenko, AIP Conf. Proc. 1800, 040019 (2017)

5. A. Tarasenko, P. Chepur, A. Gruchenkova, MATEC Web of Conf. 73, 01018 (2016)

6. A. Tarasenko, P. Chepur, S. Chirkov, AIP Conf. Proc. 1772, 060010 (2016)

7. A. Tarasenko, P. Chepur, A. Gruchenkova, AISC 692, 936-943 (2018)

8. S. Chirkov, A. Tarasenko, P. Chepur, IOP Conf. Series: Earth and Environ. Sci. 90, 012102 (2017)

9. A.A. Tarasenko, P.A. Konovalov, F.F. Zekhniev, P.V. Chepur, D.A. Tarasenko, Soil Mech. and Found. Eng. 53(6), 405-411 (2017)

10. A. Tarasenko, P. Chepur, A. Gruchenkova, AIP Conf. Proc. 1772, 060011 (2016)

11. A.A. Tarasenko, P.V. Chepur, A.A. Gruchenkova, J. of Phys.: Conf. Series 1015, 032047 (2018)

12. A.V. Beloborodov, Vestnik of the Ural Fed. Univ. 1, 78-81 (2005)

13. A.S. Gorelov, Neodnorodnye gruntovye osnovaniya $i$ ikh vliyanie na rabotu vertikal'nykh stal'nykh rezervuarov (Nedra, Saint Petersburg, 2009)

14. RD-23.020.00-KTN-271-10, Pravila tekhnicheskoy diagnostiki rezervuarov (OAO AK "Transneft", Moscow, 2010)

15. GOST 31385-2016, Rezervuary vertikal'nye tsilindricheskie stal'nye dlya nefti $i$ nefteproduktov. Obshchie tekhnicheskie usloviya (Standartinform, Moscow, 2016)

16. V.V. Krivirotov, A.V. Kalina, V.D. Tretyakov, E.A. Tikhanov, K.E. Parfenov, Vestnik of the Ural Fed. Univ. 4, 61-76 (2013) 